\title{
Integrating molecular and structural findings: Wnt as a possible actor in shaping cognitive impairment in Cornelia de Lange syndrome
}

\author{
Laura Avagliano ${ }^{1}$, Paolo Grazioli', Milena Mariani ${ }^{2}$, Gaetano P. Bulfamante ${ }^{1}$, Angelo Selicorni ${ }^{2}$ \\ and Valentina Massa ${ }^{1 *}$ (i)
}

\begin{abstract}
Cornelia de Lange Syndrome (CdLS) is a choesinopathy: a severe genetic disorder caused by mutations in the cohesin complex genes. The phenotype is characterized by typical facial dysmorphism, growth impairment and multiorgan abnormalities including brain alterations. Wnt pathway is known to play a fundamental role in central nervous system development and it has been shown that Wnt pathway is disrupted in CdLS animal models and patients cells. In this review we investigate the possible link between Wnt pathway disruption and brain abnormalities in Cornelia de Lange Syndrome as such molecular impairment could lead to an abnormal embryonic development resulting in brain abnormalities (i.e. microcephaly, cerebellar hypoplasia, abnormal cortical development) in patients with Cornelia de Lange Syndrome.
\end{abstract}

Keywords: Brain abnormalities, Cornelia de Lange syndrome, Wnt pathway

\section{Background}

CdLS is a choesinopathy disorder caused by heterozygous or X-linked mutations in the cohesion core subunits $S M C 1 A, S M C 3, R A D 21$, or in cohesion components NIPBL and HDAC8 [1-6]. CdLS manifests with typical facial dysmorphism (hirsute forehead, arched eyebrows with synophyrs, short nose with depressed nasal bridge, anteverted nares, long and smooth philtrum, thin lips, downwards turning corners of the mouth), growth impairment and multiorgan abnormalities including limb anomalies, congenital heart defects, gastrointestinal disease and brain alterations. Developmental disability invariably affects patients with CdLS even if about $20-30 \%$ of patients show mild impairment. Even if clinical signs of the neurodevelopmental impairment of multifactorial origin might be related to anatomical brain abnormalities, only few studies report brain features.

\footnotetext{
* Correspondence: valentina.massa@unimi.it

${ }^{1}$ Department of Health Sciences, San Paolo Hospital Medical School

University of Milan, Via A. di Rudinì, 8, 20142 Milan, Italy

Full list of author information is available at the end of the article
}

Wnts are secreted glycoproteins that activate signaling cascades involved in cell fate specification, polarity and migration, implicated in many aspects of embryo development. Wnt genes and signaling proteins are known to play a major role in fetal brain development $[7,8]$ and Wnt signaling pathway alterations have been associated to a number of central nervous system diseases [7].

The present review focuses on brain findings of patients affected by CdLS, exploring a possible correlation with Wnt signaling.

\section{Brain development and Wnt pathway}

The human central nervous system (brain and spinal cord) is formed during the process known as neurulation that occurs between 20 and 27 days post-fertilization [9]. In the previous developmental phase, called gastrulation, the ectoderm is formed, which will thicken in response to an array of molecular signals released by the underlying notochord, originating the neural plate. This plate of ectodermal cells will form the neural tube by elevating, juxtaposing and fusing along the midline, thanks to a process of folding up on its anterior-posterior axis. At 
the end of the fusion along the midline, a hollow tube forms, called the neural tube [10].

During gastrulation, as the neural plate is forming, neural crest cells are organized at the edge of the prospective neural plate [11]. Neural crest cells are initially located within the dorsal part of the neural tube, at the edge of the neural plate, bordering between neuronal and nonneuronal ectoderm; during neural tube closure, neural crest cells delaminate from the dorsal neural tube along the embryo body axis and migrate, differentiating into multiple cell types, such as neurons and glial cells of the peripheral nervous system and structures such as cranial bones, cranial cartilage, dentin and dental pulp $[12,13]$.

Just before neural tube closure, the anterior extremity of the tube begins to expand forming the three primary brain vesicles [9]. The prosencephalon is the most anterior of these vesicles, which will become the forebrain. The middle vesicle is called the mesencephalon and represents the precursor of midbrain structures. The rhombencephalon is the most posterior vesicle and represents the embryonic hindbrain [9]. These three primary vesicles are visible approximately at day 28 post-fertilization. The prosencephalon and rhomboencephalon soon divide forming the secondary brain vesicles: telencephalon and diencephalon rostrally and metencephalon and myelencephalon caudally. All these structures are visible by day 49 postfertilization [9]. Cerebral hemispheres develop because of sagittal folding and division of the telencephalon and rapidly expand and completely cover the diencephalon; the telencephalon augments in dimension for the active formation and differentiation of neurons and glia: from the germinal neuroepithelium, stem cells give rise to neurons and non-neuronal cells, thereafter immature neurons migrate to colonize the forebrain, midbrain, hindbrain in different spatial distribution of cortical layers, nuclei, and ganglia. At nine weeks of gestation, brain lobes are formed, and then sulci and gyri develop, together with the formation of the corpus callosum, representing the intercommissural connections [9]. The cortex and medullary center develop, as well as the basal ganglia, lamina terminalis, hippocampus, corpus striatum and olfactory system.

The diencephalon will form the thalamus, epithalamus, hypothalamus, subthalamus, neurohypophysis, pineal gland, retina, optic nerve and mamillary bodies.

The mesencephalon develops into the lamina quadrigemina, the cerebral peduncles and the cerebral aqueduct. Pons and cerebellum originate from the metencephalon whereas the medulla oblongata develops from the myelencephalon.

To warrant a proper formation and function of the central nervous system, the complex developmental process described above must be coordinated by the developmental activity of a vast number of genes and proteins. The Wnt pathway has been shown to intervene in all steps of brain developmental process [8]: for example Wnt signals are involved in generation and migration of neural crest cells [12-15] implicated in the cranio-facial development [16-19]; Wnt proteins provide positional information within the embryo for anteriorposterior axis specification of the neural plate [20], regulating morphogenesis of the neural tube [21-23]: anterior-posterior specification of the neural plate and neural tube is dependent on graded Wnt signaling [8] requiring an inhibition of Wnt signaling in the anterior zone for proper anterior-posterior patterning of the early central nervous system development [8]; Wnt signals also intervene in neuronal cells development participating in neuron formation from the neuronal stem cells, neuronal proliferation and specification, neuronal migration and maturation including axon growth, dendrites formation and synaptogenesis $[7,8]$.

Expression of the Wnt genes during brain development is summarized in Fig. 1, with an overlapping spatial and temporal pattern [8].

In terms of malformation, for example, $W_{n t 1^{-/}} \mathrm{em}-$ bryos lack the entire midbrain and cerebellum, which originates from the anterior metencephalon [24, 25]; moreover, it has been shown that inactivation of $\beta$-catenin gene by Wnt1-Cre-mediated deletion results in dramatic brain malformation and failure of craniofacial development [26].

\section{Brain abnormalities in CdLS}

Microcephaly has been frequently reported in patients affected by CdLS, also associated with brachycephaly or plagiocephaly, both in infants and adults. No large cohort studies are available regarding type and prevalence of central nervous system anomalies in infants with CdLS (see for example Kline et al. 1993 and Selicorni et al. 2007 [27, 28]) and even fewer data are available in fetuses (see for example Avagliano et al. 2017 [29]); hence most information is related to single case reports. Parenchymal volume loss may affect both white and gray matter, especially involving midline: frontal or temporal lobes hypoplasia have been reported in possible association with hypoplasia of corpus callosum, pituitary, ventral pons and cerebellar vermian structures [30-39].

The frequency of the observed brain abnormalities in the reported cases are summarized in Table 1.

Corpus callosum abnormalities have been resolved by magnetic resonance imaging (MRI) and described as short or thin or hypoplastic [37, 39] (Fig. 2). Such abnormalities have also been reported at autopsy showing thin corpus callosum with rudimentary septum pellucidum in a case of CdLS associated with septo-optic dysplasia [40].

Mild dilatation of the ventricles system could be appreciated by MRI $[39,41,42]$ or noted by neuropathological investigation [43] with observation of moderated 

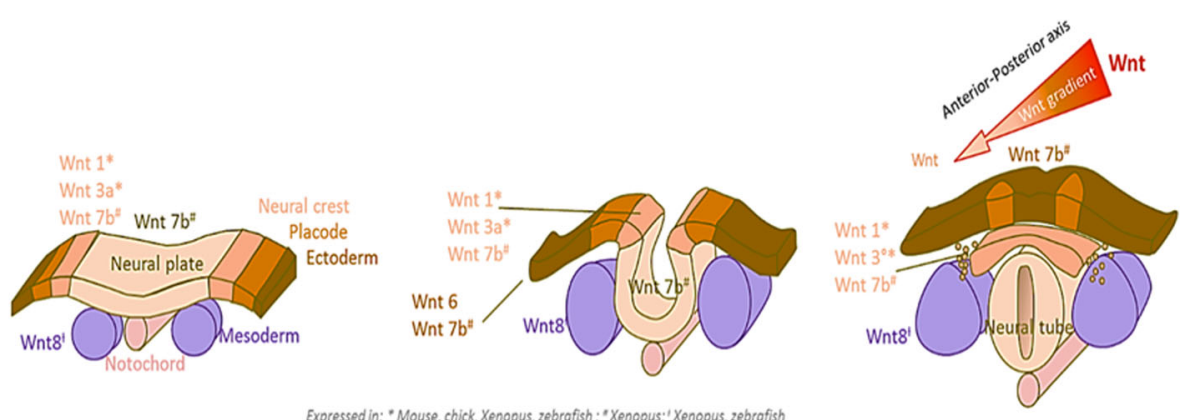

Expressed in: "Mouse, chick, Xenopus, zebrofish; ; Xenopus:" 'Xenopus, zebrofish

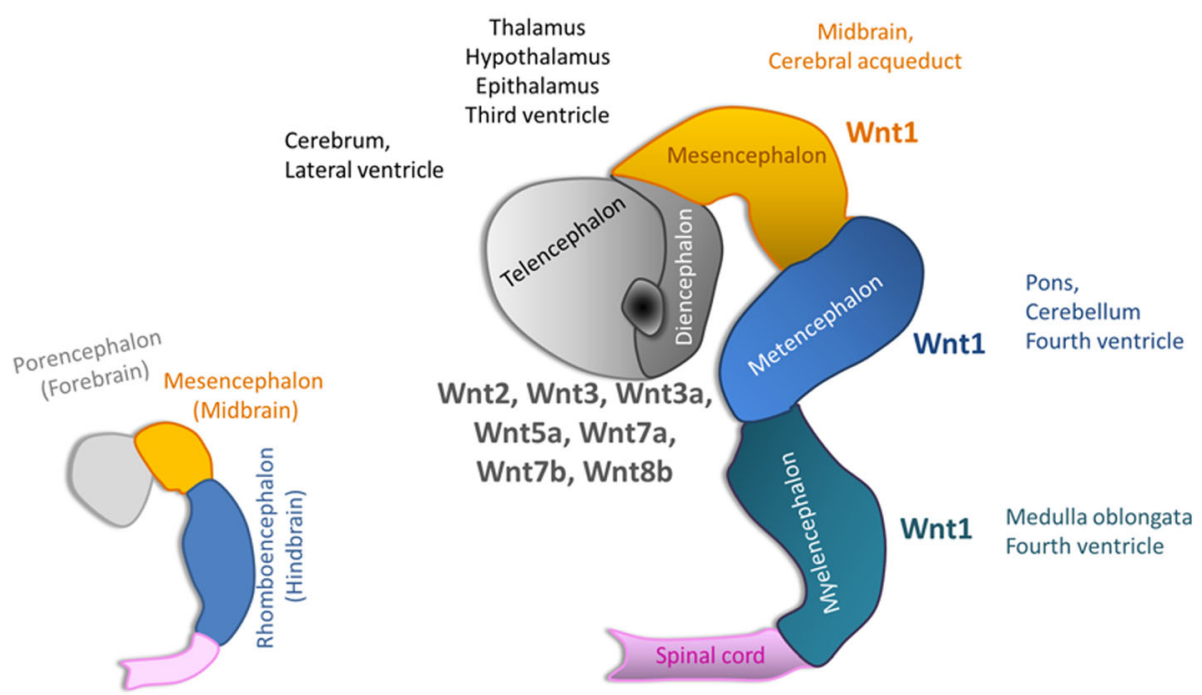

Wnt1, Wnt3, Wnt3a, Wnt4, Wnt5a,

Wnt7a, Wnt7b

Fig. 1 Wnt genes expression during the brain developmental process, from gastrulation to the differentiation of the structures forming the central nervous system. Note the spatial and temporal overlapping of the gene expression pattern

dilatation of third [43] or fourth ventricle [33, 40], cerebral aqueduct and central canal of the spine [40].

Pituitary abnormalities have been reported including: reduction in size of the gland [39, 40, 44], cysts [39, 43, 45] and tumors such as microadenoma [39] or one case of invasion of the hypophysis by suprasellar germinoma [46]. In this last case the hypophysis was large. Other reports showed an unremarkable pituitary gland [31, 36-38]. Histologically, few cases were reported showing absence of basophilic cells [30, 40, 43].

Brain stem abnormalities have been observed radiologically with volume loss predominantly involving the pons $[38,39]$. Autopsy data also report cases of reduced brain stem $[33,35,43]$ with a specific reduction of the ventral portion of the pons [33, 35].

Cerebellum showed volume loss at head computed tomography imaging [38] and MRI [38], possibly revealing vermian hypolplasia [37, 39, 42]. Autopsy reports showed size reduction of the cerebellum (Fig. 2) [35, 43] and partial aplasia of the vermis involving the posterior part [40]. Histologically, cases with a focal loss of Purkinje cells [40] and granular cells $[35,40]$ have been reported associated with the presence of rudimentary superior cerebellar peduncles [40]. Heterotopic cell nests have been sometimes reported in the cerebellar white matter [35] whereas in other cases normal neuronal density and morphology have been described [36].

Cisterna magna has been described radiologically $[39,42]$ and anatomically $[40]$ as enlarged up to "mega" cisterna magna.

Localized or diffuse malformations of cortical development have been frequently reported by neuroimaging [38], described as abnormal convolution characterized by gyral simplification [38, 39]. Autopsy findings also showed abnormal sulcal pattern [44] characterized by immaturity of the cerebral gyri (Fig. 2) [32, 35] with simple convolution pattern [32, 35], few shallow sulci running randomly [40] or abnormally oriented gyri resulting in strongly vertical pitch [36]. Other reports showed unduly narrow cerebral gyri $[30,33]$ with 
Table 1 Frequency of brain disorders in reported cases with deep brain investigations

\begin{tabular}{|c|c|c|c|c|c|c|c|c|c|c|}
\hline Reference & Method & $\begin{array}{l}\text { Microcephaly/ } \\
\text { Microencephaly }\end{array}$ & $\begin{array}{l}\text { Cerebral or } \\
\text { lobar atrophy }\end{array}$ & $\begin{array}{l}\text { Brain stem } \\
\text { size } \\
\text { reduction }\end{array}$ & $\begin{array}{l}\text { Malformation } \\
\text { cortical } \\
\text { development }\end{array}$ & $\begin{array}{l}\text { Corpus } \\
\text { callosum } \\
\text { anomalies }\end{array}$ & $\begin{array}{l}\text { Ventricles } \\
\text { dilatation }\end{array}$ & $\begin{array}{l}\text { Cerebellar } \\
\text { anomalies }\end{array}$ & $\begin{array}{l}\text { Cisterna magna } \\
\text { enlargement }\end{array}$ & Pituitary \\
\hline Roshan Lal 2016 & MRI & $4 / 15$ & $6 / 15$ & $3 / 15$ & $1 / 15$ & $3 / 15$ & $3 / 15$ & $5 / 15$ & $5 / 15$ & $4 / 15$ \\
\hline Whitehead 2015 & $\begin{array}{l}\text { MRI and/ } \\
\text { or CT }\end{array}$ & $6 / 7$ & $6 / 8$ & $5 / 7$ & $5 / 8$ & NME & NME & $6 / 8$ & NME & $0 / 8$ \\
\hline Lalatta 2007 & MRI & $1 / 2$ & $1 / 2$ & $0 / 2$ & $0 / 2$ & $1 / 2$ & $0 / 2$ & $1 / 2$ & $0 / 2$ & $0 / 2$ \\
\hline Vuilleumier 2002 & Autopsy & $1 / 1$ & $1 / 1$ & $0 / 1$ & $1 / 1$ & NME & $0 / 1$ & $0 / 1$ & $0 / 1$ & $0 / 1$ \\
\hline Yamaguchi 1999 & Autopsy & $1 / 1$ & $1 / 1$ & $1 / 1$ & $1 / 1$ & NME & NME & $1 / 1$ & NME & NME \\
\hline Sasaki 1996 & Autopsy & $1 / 1$ & $1 / 1$ & $1 / 1$ & $1 / 1$ & NME & $1 / 1$ & NME & NME & NME \\
\hline Hayashi 1996 & Autopsy & NME & NME & $1 / 1$ & $1 / 1$ & $1 / 1$ & $1 / 1$ & $1 / 1$ & $1 / 1$ & $1 / 1$ \\
\hline Sato 1986 & Autopsy & $1 / 1$ & $1 / 1$ & $0 / 1$ & $1 / 1$ & a & $0 / 1^{\mathrm{a}}$ & $0 / 1$ & NME & a \\
\hline France 1969 & Autopsy & $2 / 2$ & NME & $2 / 2$ & $2 / 2^{c}$ & NME & $1 / 2$ & $1 / 2$ & NME & $1 / 2$ \\
\hline Mc Artur 1967 & Autopsy & $1 / 1$ & $1 / 1$ & NME & $0 / 1$ & NME & NME & $0 / 1$ & NME & $0 / 1$ \\
\hline Hart 1965 & Autopsy & $1 / 1$ & NME & $1 / 1$ & $1 / 1$ & NME & NME & NME & NME & $1 / 1$ \\
\hline Schlesinger 1963 & Autopsy & $2 / 2$ & $2 / 2$ & NME & $2 / 2$ & NME & NME & NME & NME & $2 / 2^{b}$ \\
\hline
\end{tabular}

Data are presented as "number of affected cases/number of total investigated cases"

$\mathrm{CT}=$ computed tomography, $\mathrm{MRI}=$ magnetic resonance imaging, NME = no explicitly mentioned

anvolved by tumor invasion

${ }^{b}$ Histological changes

${ }^{c}$ Not severe gyral abnormalities but histological signs of malformation of cortical development

marked kinking [33] and wide intergyral sulci [30]. Other cases reported a relatively normal pattern of convolution with slight underdevelopment of the frontal operculae resulting in partial uncovering of the insula (Fig. 2) [43]. Histologically, focal zones of ectopic neurons have been reported, scattered in the subcortical white matter [40], as well as neuronal loss [40], and reduction in the number of oligodendroglia [33] with impaired myelinization $[43,47]$. It has been suggested that the observation of focal demyelinization in CdLS may be related to incomplete myelin formation [36] rather than myelin degeneration as previously proposed [30]. Sometimes gliosis has been reported [30, 39, 40, 43] whereas in other cases was absent [32, 33, 36] suggesting that neurodegenerative changes are not specific features [36].
Brain abnormalities in CdLS are summarized in Fig. 3.

\section{Wnt signaling pathway in Cornelia de Lange}

Several experimental models have been used to dissect molecular mechanisms underlying CdLS. In particular, gene expression alterations have been assessed using $D$. melanogaster [48, 49], D. rerio [50-54], mutant mouse $[1,2,55]$ and human cells $[5,51,54]$.

In all studied models, abnormalities in the Wnt signalling pathway have been reported: gene-expression alterations in Wnt components have been shown in fibroblasts derived from patients $[5,51,54]$. In Drosophila, Nipped-B, ortholog of mammalian NIPBL, is known to regulate Ultrabithorax [56] a key repressor in the dorsoventral patterning of Wingless [57], mammalian ortholog

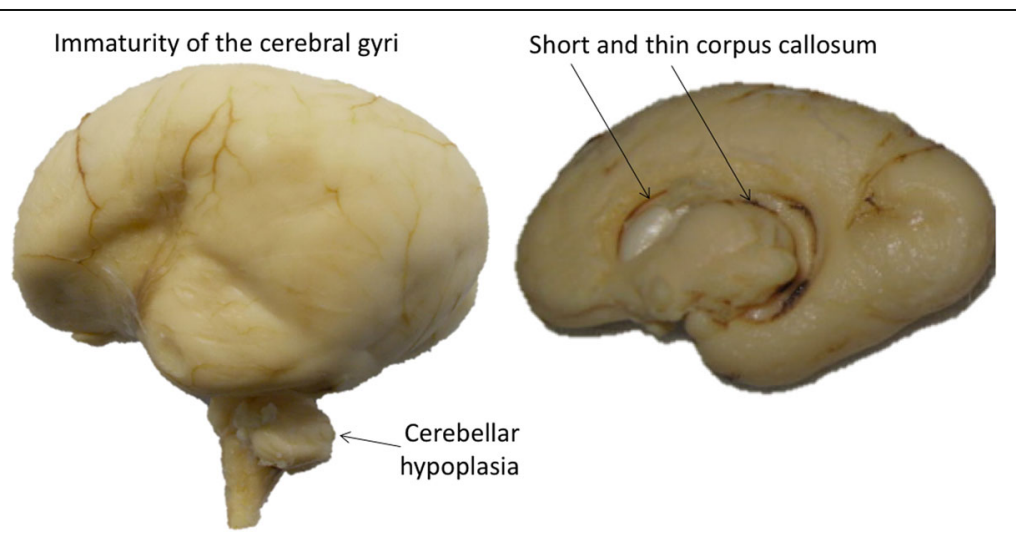

Fig. 2 Example of brain abnormalities in a fetus at 25 weeks of gestation. Note the size reduction of the cerebellum with severe volume loss; the immaturity of sulcal pattern with slight underdevelopment of the frontal operculae for the gestational age, resulting in uncovering of the insula; the abnormalities of the corpus callosum that appears thin (in the trunk area) and short (with absence of the genu) 


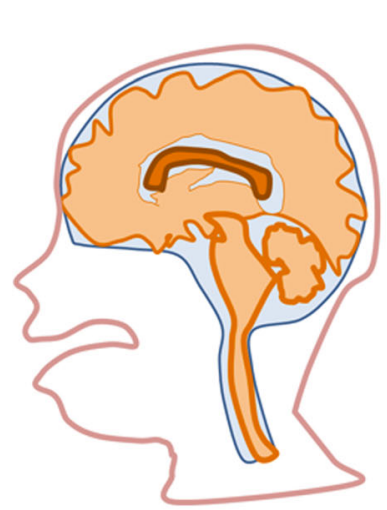

Normal

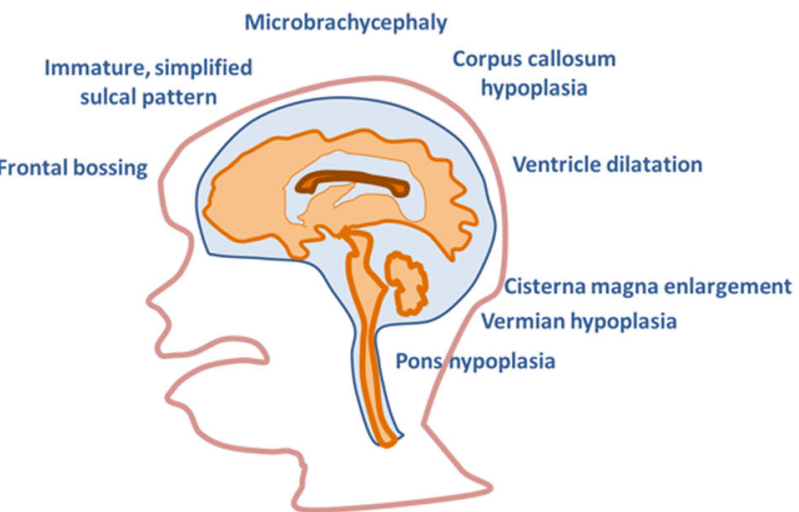

Cornelia de Lange syndrome

Fig. 3 Summary of the brain abnormalities in CdLS. Cartoons compare the sagittal section of normal brain (on the left) with the sagittal section of affected brain (on the right). In the same patient, often more than one of the presented brain abnormalities are present, however only seldom all lesions are detected in the same patient

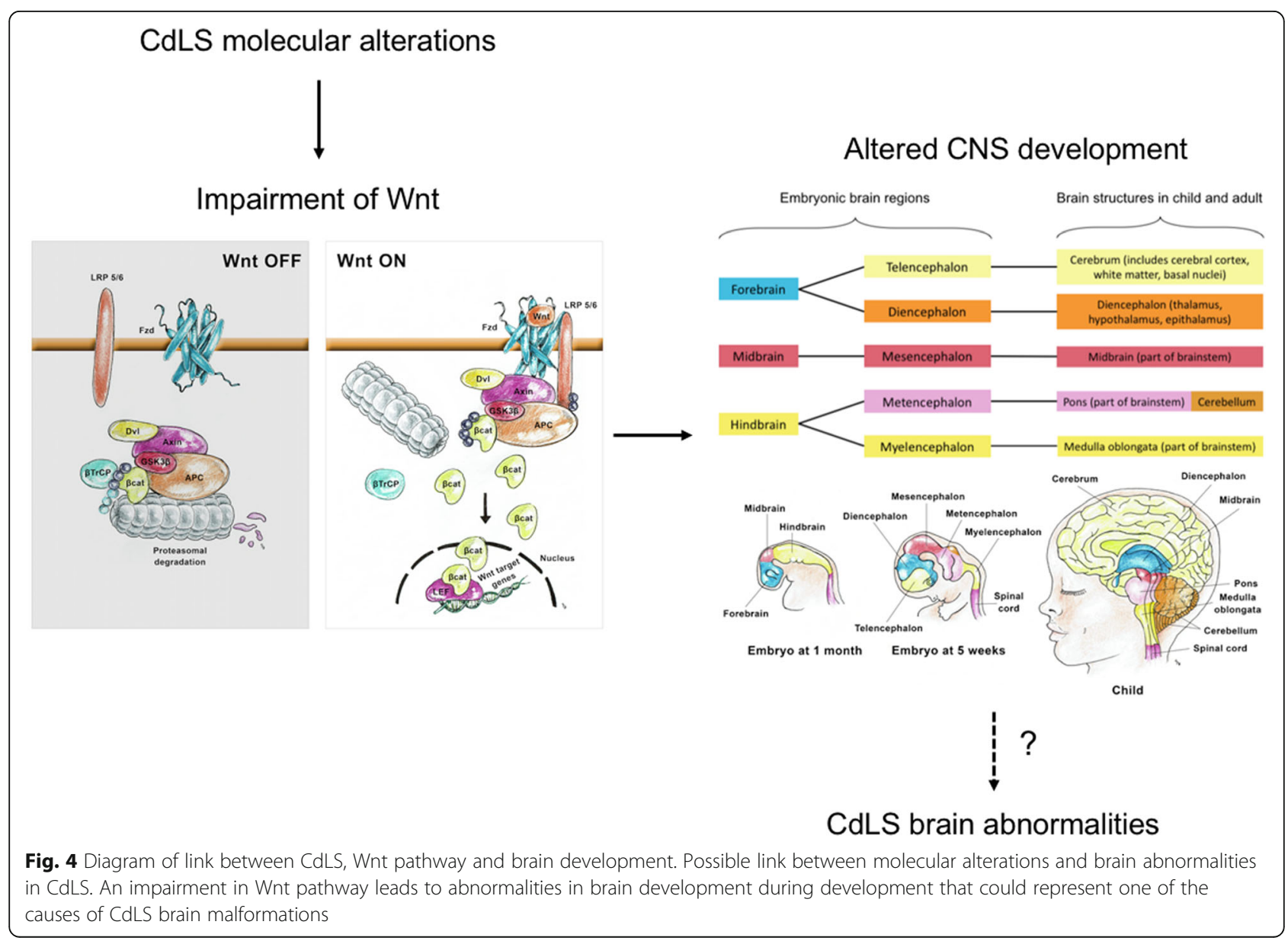


of Wnt. Moreover, in a recent paper investigating Rad21 reduced levels in zebrafish embryos, it was shown that heart looping is altered due to failure of neural crest cells to populate developing heart. Analysis of trascriptome revealed that among others, Wnt signalling pathway components were mis-expressed in rad21-depleted embryos [58]. In D. rerio and human fibroblasts modeling Nipbl [51] and Smc1a [54] haploinsufficiency, alterations of protein levels of the canonical Wnt pathway components have been reported. Intriguingly, in these models, chemical activation of canonical Wnt pathway has been shown to rescue the adverse phenotypes in the developing nervous system, suggesting a causative role of Wnt pathway alterations in brain abnormalities in CdLS (Fig. 4).

\section{Conclusions}

In conclusion, this rare but severely debilitating syndrome, although described in the 1930s, is still in search of a mechanistic and neurological definition. The syndrome presents an array of congenital malformations but it is invariably associated with cognitive impairment that somehow overlaps with the so-called "autism spectrum disorders". Here, we summarize findings that link a molecular pathway found to be perturbed in all studied models with brain morphological developmental abnormalities reported in CdLS patients, summarizing molecular and structural features that could be responsible for, at least in part, the cognitive alterations. Importantly, given the genetic heterogeneity it will be important to dissect possible differences between patients in future studies.

\section{Abbreviations}

CdLS: Cornelia de Lange Syndrome; CT: Computed tomography;

MRI: Magnetic resonance imaging

\section{Acknowledgments}

The authors are grateful to the Italian National Association of Volunteers Cornelia de Lange for support and inspiration. We would also like to express our deep gratitude to Ms. Susanna Bruga for graphic support. This work has been supported by Fondazione Cariplo, grant n. 2015-0783 to VM, and by Fondazione Mariani (Como, Italy) to AS.

\section{Funding}

Fondazione Cariplo, grant n. 2015-0783 to VM.

\section{Availability of data and materials}

Not applicable as this is a review. All information was retrieved from published papers available on Pubmed.

\section{Authors' contributions}

Conception and design of the article by LA, VM. LA performed the literature search, drafted the manuscript, realized figs. PG and MM expanded the literature research and assembly figs. GB revised clinical database and provide archive images. GB and AS actively interpreted the clinical findings. All authors read, edited, and approved the final manuscript.

\section{Ethics approval and consent to participate}

Not applicable.

\section{Consent for publication}

Not applicable.

\section{Competing interests}

The authors declare that they have no competing interests.

\section{Publisher's Note}

Springer Nature remains neutral with regard to jurisdictional claims in published maps and institutional affiliations.

\section{Author details}

${ }^{1}$ Department of Health Sciences, San Paolo Hospital Medical School University of Milan, Via A. di Rudini, 8, 20142 Milan, Italy. ${ }^{2}$ UOC Pediatria, ASST Lariana, Como, Italy.

Received: 6 July 2017 Accepted: 10 November 2017

Published online: 21 November 2017

\section{References}

1. Krantz ID, McCallum J, DeScipio C, Kaur M, Gillis LA, Yaeger D, et al. Cornelia de Lange syndrome is caused by mutations in NIPBL, the human homolog of Drosophila Melanogaster nipped-B. Nat Genet. 2004;36:631-5. Available from: https://www.ncbi.nlm.nih.gov/pubmed/15146186.

2. Tonkin ET, Wang TJ, Lisgo S, Bamshad MJ, Strachan T. NIPBL, encoding a homolog of fungal Scc2-type sister chromatid cohesion proteins and fly nipped-B, is mutated in Cornelia de Lange syndrome. Nat Genet. 2004;36: 636-41. Available from: https://www.ncbi.nlm.nih.gov/pubmed/15146185.

3. Musio A, Selicorni A, Focarelli ML, Gervasini C, Milani D, Russo S, et al. $X$-linked Cornelia de Lange syndrome owing to SMC1L1 mutations. Nat Genet. 2006;38:528-30. Available from: https://www.ncbi.nlm.nih.gov/ pubmed/16604071.

4. Deardorff MA, Kaur M, Yaeger D, Rampuria A, Korolev S, Pie J, et al. Mutations in cohesin complex members SMC3 and SMC1A cause a mild variant of cornelia de Lange syndrome with predominant mental retardation. Am J Hum Genet. 2007;80:485-94. Available from: https://www.ncbi.nlm.nih.gov/pubmed/17273969.

5. Deardorff MA, Bando M, Nakato R, Watrin E, Itoh T, Minamino M, et al HDAC8 mutations in Cornelia de Lange syndrome affect the cohesin acetylation cycle. Nature. 2012;489:313-7. Available from: https://www.ncbi. nlm.nih.gov/pubmed/22885700.

6. Deardorff MA, Wilde JJ, Albrecht M, Dickinson E, Tennstedt S, Braunholz D, et al. RAD21 mutations cause a human cohesinopathy. Am J Hum Genet. 2012;90:1014-27. Available from: https://www.ncbi.nlm.nih.gov/pubmed/ 22633399.

7. Inestrosa NC, Varela-Nallar L. Wnt signalling in neuronal differentiation and development. Cell Tissue Res. 2015;359:215-23. Available from: https://www. ncbi.nlm.nih.gov/pubmed/25234280.

8. Mulligan KA, Cheyette BN. Wnt signaling in vertebrate neural development and function. J Neurolmmune Pharmacol. 2012;7:774-87. Available from: https://www.ncbi.nlm.nih.gov/pubmed/23015196.

9. Stiles J, Jernigan TL. The basics of brain development. Neuropsychol Rev. 2010;20:327-48. Available from: https://www.ncbi.nlm.nih.gov/pubmed/ 21042938 .

10. Nikolopoulou E, Galea GL, Rolo A, Greene ND, Copp AJ. Neural tube closure: cellular, molecular and biomechanical mechanisms. Development. 2017;144:552-66. Available from: https://www.ncbi.nlm.nih.gov/pubmed/ 28196803.

11. Fernandez-Garre P, Rodriguez-Gallardo L, Gallego-Diaz V, Alvarez IS, Puelles L. Fate map of the chicken neural plate at stage 4. Development. 2002;129:2807-22. Available from: https:/www.ncbi.nlm.nih.gov/pubmed/12050131.

12. Mishina Y, Snider TN. Neural crest cell signaling pathways critical to cranial bone development and pathology. Exp Cell Res. 2014;325:138-47. Available from: https://www.ncbi.nlm.nih.gov/pubmed/24509233.

13. Noisa P, Raivio T. Neural crest cells: from developmental biology to clinical interventions. Birth Defects Res C Embryo Today. 2014;102:263-74. Available from: https://www.ncbi.nlm.nih.gov/pubmed/25226872.

14. Brugmann SA, Goodnough LH, Gregorieff A, Leucht P, ten Berge D, Fuerer C, et al. Wnt signaling mediates regional specification in the vertebrate face. Development. 2007;134:3283-95. Available from: https:/www.ncbi.nlm.nih. gov/pubmed/17699607.

15. Lee HY, Kléber M, Hari L, Brault V, Suter U, Taketo MM, et al. Instructive role of Wnt/beta-catenin in sensory fate specification in neural crest stem cells. Science. 2004;303:1020-3. Available from: https://www.ncbi.nlm.nih.gov/ pubmed/14716020. 
16. Fu J, Ivy Yu HM, Maruyama T, Mirando AJ, Hsu W. Gpr177/mouse Wntless is essential for Wnt-mediated craniofacial and brain development. Dev Dyn. 2011;240:365-71. Available from: https://www.ncbi.nlm.nih.gov/pubmed/ 21246653.

17. Song L, Li Y, Wang K, Wang YZ, Molotkov A, Gao L, et al. Lrp6-mediated canonical Wnt signaling is required for lip formation and fusion. Development. 2009;136:3161-71. Available from: https://www.ncbi.nlm.nih.gov/pubmed/ 19700620.

18. Lan Y, Ryan RC, Zhang Z, Bullard SA, Bush JO, Maltby KM, et al. Expression of Wnt9b and activation of canonical Wnt signaling during midfacial morphogenesis in mice. Dev Dyn. 2006;235:1448-54. Available from: https://www.ncbi.nlm.nih.gov/pubmed/16496313.

19. Geetha-Loganathan P, Nimmagadda S, Antoni L, Fu K, Whiting CJ, Francis-West $P$, et al. Expression of WNT signalling pathway genes during chicken craniofacial development. Dev Dyn. 2009;238:1150-65. Available from: https://www.ncbi.nlm.nih.gov/pubmed/19334275.

20. Kiecker C, Niehrs C. A morphogen gradient of Wnt/beta-catenin signalling regulates anteroposterior neural patterning in Xenopus. Development. 2001;128:4189-201. Available from: https://www.ncbi.n/m.nih.gov/pubmed/ 11684656.

21. Carter M, Chen X, Slowinska B, Minnerath S, Glickstein S, Shi L, et al. Crooked tail (Cd) model of human folate-responsive neural tube defects is mutated in Wnt coreceptor lipoprotein receptor-related protein 6. Proc Natl Acad Sci U S A. 2005;102:12843-8. Available from: https://www.ncbi.nlm.nih. gov/pubmed/16126904.

22. Kokubu C, Heinzmann U, Kokubu T, Sakai N, Kubota T, Kawai M, et al. Skeletal defects in ringelschwanz mutant mice reveal that Lrp6 is required for proper somitogenesis and osteogenesis. Development. 2004;131:5469-80. Available from: https://www.ncbi.nlm.nih.gov/pubmed/15469977.

23. Pinson Kl, Brennan J, Monkley S, Avery BJ, Skarnes WC. An LDL-receptor-related protein mediates Wnt signalling in mice. Nature. 2000;407:535-8. Available from: https://www.ncbi.nlm.nih.gov/pubmed/11029008.

24. McMahon AP, Bradley A. The Wnt-1 (int-1) proto-oncogene is required for development of a large region of the mouse brain. Cell. 1990;62:1073-85. Available from: https://www.ncbi.nlm.nih.gov/pubmed/2205396.

25. Thomas KR, Capecchi MR. Targeted disruption of the murine int-1 proto-oncogene resulting in severe abnormalities in midbrain and cerebellar development. Nature. 1990;346:847-50. Available from: https://www.ncbi.nlm.nih.gov/pubmed/2202907.

26. Brault V, Moore R, Kutsch S, Ishibashi M, Rowitch DH, McMahon AP, et al. Inactivation of the beta-catenin gene by Wnt1-Cre-mediated deletion results in dramatic brain malformation and failure of craniofacial development. Development. 2001:128:1253-64. Available from: https://www.ncbi.nlm.nih.gov/pubmed/11262227.

27. Kline AD, Stanley C, Belevich J, Brodsky K, Barr M, Jackson LG. Developmental data on individuals with the Brachmann-de Lange syndrome. Am J Med Genet. 1993:47:1053-8.

28. Selicorni A, Russo S, Gervasini C, Castronovo P, Milani D, Cavalleri F, et al. Clinical score of 62 Italian patients with Cornelia de Lange syndrome and correlations with the presence and type of NIPBL mutation. Clin Genet. 2007:72:98-108

29. Avagliano L, Bulfamante GP, Massa V. Cornelia de Lange syndrome: To diagnose or not to diagnose in utero? Birth Defects Res. 2017;109:771-7. Available from: https://www.ncbi.nlm.nih.gov/pubmed/28544538

30. Schlesinger B, Clayton B, Bodian M, Jones KV. Typus degenerativus Amstelodamensis. Arch Dis Child. 1963;38:349-57. Available from: https://www.ncbi.nlm.nih.gov/pubmed/14058809.

31. McArthur RG, Edwards JH. De Lange syndrome: report of 20 cases. Can Med Assoc J. 1967;96:1185-98. Available from: https://www.ncbi.nlm.nih.gov/ pubmed/6022788.

32. Sato A, Kajita A, Sugita K, Izumi T, Fukuyama Y, Funata N, et al. Cornelia de Lange syndrome with intracranial germinoma. Acta Pathol Jpn. 1986;36: 143-9. Available from: https://www.ncbi.nlm.nih.gov/pubmed/3962671.

33. Sasaki T, Kaga K, Ohira Y, Ogawa Y, Fukushima Y. Temporal bone and brain stem histopathological findings in Cornelia de Lange syndrome. Int J Pediatr Otorhinolaryngol. 1996;36:195-204. Available from: https://www.ncbi. nlm.nih.gov/pubmed/8864803.

34. Ozkinay F, Cogulu O, Gunduz C, Levent E, Ozkinay C. A case of Brachman de Lange syndrome with cerebellar vermis hypoplasia. Clin Dysmorphol. 1998:7:303-5. Available from: https://www.ncbi.nlm.nih.gov/ pubmed/9823500
35. Yamaguchi K, Ishitobi F. Brain dysgenesis in Cornelia de Lange syndrome. Clin Neuropathol. 1999;18:99-105. Available from: https://www.ncbi.nlm.nih. gov/pubmed/10192706.

36. Vuilleumier N, Kovari E, Michon A, Hof PR, Mentenopoulos G, Giannakopoulos P et al. Neuropathological analysis of an adult case of the Cornelia de Lange syndrome. Acta Neuropathol. 2002;104:327-32. Available from: https://www. ncbi.nlm.nih.gov/pubmed/12172920

37. Lalatta F, Russo S, Gentilin B, Spaccini L, Boschetto C, Cavalleri F, et al. Prenatal/neonatal pathology in two cases of Cornelia de Lange syndrome harboring novel mutations of NIPBL. Genet Med. 2007;9:188-94. Available from: https://www.ncbi.nlm.nih.gov/pubmed/17413424.

38. Whitehead MT, Nagaraj UD, Pearl PL. Neuroimaging features of Cornelia de Lange syndrome. Pediatr Radiol. 2015;45:1198-205. Available from: https://www.ncbi.nlm.nih.gov/pubmed/25701113.

39. Roshan Lal TR, Kliewer MA, Lopes T, Rebsamen SL, O'Connor J, Grados MA, et al. Cornelia de Lange syndrome: correlation of brain MRI findings with behavioral assessment. Am J Med Genet C Semin Med Genet. 2016:172:190-7. Available from: https://www.ncbi.nlm.nih.gov/pubmed/27164360.

40. Hayashi M, Sakamoto K, Kurata K, Nagata J, Satoh J, Morimatsu Y. Septo-optic dysplasia with cerebellar hypoplasia in Cornelia de Lange syndrome. Acta Neuropathol. 1996;92:625-30. Available from: https:/www.ncbi.nlm.nih.gov/ pubmed/8960322

41. Silva-Hernàndez F, Rodrìguez-Cuadrado Gl, Martin-Ruaigip RJ, Barreras-Avila L, Gonzàlez-Chevere B, Valentin-Rivera R, et al. Functional brain imaging in Cornelia de Lange syndrome: case report and literature review. Bol Asoc Med P R. 2015;107:73-7. Available from: https:/www.ncbi.nlm.nih.gov/pubmed/ 26434089.

42. Bettini LR, Locatelli L, Mariani M, Cianci P, Giussani C, Canonico F, et al. Cervical spine malformation in cornelia de lange syndrome: a report of three patients. Am J Med Genet A. 2014;164A:1520-4. Available from: https://www.ncbi.nlm.nih.gov/pubmed/24668777.

43. France NE, Crome L, Abraham JM. Pathological features in the de Lange syndrome. Acta Paediatr Scand. 1969;58:470-80. Available from: https://www.ncbi.n/m.nih.gov/pubmed/5365170.

44. Hart ZH, Jaslow Rl, Gomez MR. The de Lange Syndrome. Am J Dis Child. 1965;109:325-32. Available from: https://www.ncbi.nlm.nih.gov/pubmed/ 14261013

45. Bjorklof K, Brundel PJ. Typus Degenerativus Amstelodamensis (Cornelia de Lange first syndrome) - congenital Hypopituitarism due to a cyst of Rathke's cleft? Acta Paediatr Scand. 1965;54:275-87.

46. Sugita K, Izumi T, Yamaguchi K, Fukuyama Y, Sato A, Kajita A. Cornelia de Lange syndrome associated with a suprasellar germinoma. Brain and Development. 1986;8:541-6. Available from: https://www.ncbi.nlm.nih.gov/ pubmed/3799924

47. Ptacek LJ, Opitz JM, Smith DW, Gerritsen T, Waisman HA. The Cornelia de Lange syndrome. J Pediatr. 1963;63:1000-20. Available from: https://www. ncbi.nlm.nih.gov/pubmed/14071035.

48. Dorsett D. The Drosophila Melanogaster model for Cornelia de Lange syndrome: implications for etiology and therapeutics. Am J Med Genet C Semin Med Genet. 2016;172:129-37. Available from: https://www.ncbi.nlm. nih.gov/pubmed/27097273.

49. Dorsett D, Krantz ID. On the molecular etiology of Cornelia de Lange syndrome. Ann N Y Acad Sci. 2009;1151:22-37. Available from: https://www. ncbi.nlm.nih.gov/pubmed/19154515.

50. Muto A, Calof AL, Lander AD, Schilling TF. Multifactorial origins of heart and gut defects in nipbl-deficient zebrafish, a model of Cornelia de Lange syndrome. PLoS Biol. 2011;9:e1001181. Available from: https://www.ncbi.nlm. nih.gov/pubmed/22039349.

51. Pistocchi A, Fazio G, Cereda A, Ferrari L, Bettini LR, Messina G, et al. Cornelia de Lange syndrome: NIPBL haploinsufficiency downregulates canonical Wnt pathway in zebrafish embryos and patients fibroblasts. Cell Death Dis. 2013;4:e866. Available from: https://www.ncbi.nlm.nih.gov/pubmed/24136230.

52. Muto A, Ikeda S, Lopez-Burks ME, Kikuchi Y, Calof AL, Lander AD, et al. Nipb and mediator cooperatively regulate gene expression to control limb development. PLoS Genet. 2014;10:e1004671. Available from: https://www. ncbi.n/m.nih.gov/pubmed/25255084.

53. Banerji R, Eble DM, lovine MK, Skibbens RV. Esco2 regulates cx43 expression during skeletal regeneration in the zebrafish fin. Dev Dyn. 2016;245:7-21. Available from: https://www.ncbi.nlm.nih.gov/pubmed/26434741.

54. Fazio G, Gaston-Massuet C, Bettini LR, Graziola F, Scagliotti V, Cereda A, et al CyclinD1 down-regulation and increased apoptosis are common features 
of Cohesinopathies. J Cell Physiol. 2016;231:613-22. Available from: https://www.ncbi.nlm.nih.gov/pubmed/26206533.

55. Kawauchi S, Calof AL, Santos R, Lopez-Burks ME, Young CM, Hoang MP, et al. Multiple organ system defects and transcriptional dysregulation in the Nipbl(+/-) mouse, a model of Cornelia de Lange syndrome. PLoS Genet. 2009;5:e1000650. Available from: https://www.ncbi.nlm.nih.gov/pubmed/ 19763162.

56. Rollins RA, Morcillo P, Dorsett D. Nipped-B, a drosophila homologue of chromosomal adherins, participates in activation by remote enhancers in the cut and Ultrabithorax genes. Genetics. 1999;152:577-93. Available from: https://www.ncbi.nlm.nih.gov/pubmed/10353901.

57. Weatherbee SD, Halder G, Kim J, Hudson A, Carroll S. Ultrabithorax regulates genes at several levels of the wing-patterning hierarchy to shape the development of the drosophila haltere. Genes Dev. 1998;12:1474-82. Available from: https://www.ncbi.nlm.nih.gov/pubmed/9585507.

58. Schuster $K$, Leeke B, Meier M, Wang Y, Newman T, Burgess S, et al. A neural crest origin for cohesinopathy heart defects. Hum Mol Genet. 2015;24:7005-16. Available from: https://www.ncbinlm.nih.gov/pubmed/26420840.

Submit your next manuscript to BioMed Central and we will help you at every step:

- We accept pre-submission inquiries

- Our selector tool helps you to find the most relevant journal

- We provide round the clock customer support

- Convenient online submission

- Thorough peer review

- Inclusion in PubMed and all major indexing services

- Maximum visibility for your research

Submit your manuscript at www.biomedcentral.com/submit
Biomed Central 